\title{
As greves e a austeridade em Portugal: Olhares, expressões e recomposições
}

Strikes and Austerity in Portugal: Perspectives, Manifestations and

Recompositions

Les grèves et l'austérité au Portugal: regards, expressions et recompositions

Hermes Augusto Costa, Hugo Dias e José Soeiro

\section{OpenEdition}

Journals

Edição electrónica

URL: http://journals.openedition.org/rccs/5584

DOI: $10.4000 /$ rccs. 5584

ISSN: $2182-7435$

\section{Editora}

Centro de Estudos Sociais da Universidade de Coimbra

Edição impressa

Data de publição: 1 Maio 2014

Paginação: 173-202

ISSN: 0254-1106

\section{Refêrencia eletrónica}

Hermes Augusto Costa, Hugo Dias e José Soeiro, « As greves e a austeridade em Portugal: Olhares, expressões e recomposições ", Revista Crítica de Ciências Sociais [Online], 103 | 2014, colocado online no dia 27 maio 2014, criado a 03 maio 2019. URL : http://journals.openedition.org/rccs/5584 ; DOI : $10.4000 /$ rccs. 5584

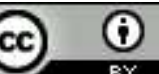




\title{
HERMES AUGUSTO COSTA, HUGO DIAS, JOSÉ SOEIRO
}

\section{As greves e a austeridade em Portugal: Olhares, expressões e recomposições}

\begin{abstract}
Num quadro de agudização das condições de trabalho e de reforço das assimetrias nas relações laborais, este texto discute a importância do fenómeno da greve em contexto de austeridade. Na primeira parte são propostos alguns olhares sociológicos sobre a greve, designadamente relacionados com as noções de democracia e regulação sociojurídica, com a(s) ideologia(s) e tensões entre ação coletiva e individual, com as escalas e controvérsias ou ainda com as temporalidades e os resultados. Na segunda parte valoriza-se um recorte quantitativo e procura-se apurar se o potencial teórico de conflitualidade se verifica em termos concretos. Por fim, relata-se uma experiência de greve de trabalhadores de um setor específico e precário (os trabalhadores da Linha Saúde 24) que permite avaliar em simultâneo os desafios que se colocam à ação sindical, bem como refletir sobre novas formas de organização do conflito social.
\end{abstract}

Palavras-chave: austeridade; direitos dos trabalhadores; greves; mercado de trabalho; precariedade laboral.

\section{Introdução}

Ao cenário de austeridade que nos últimos anos se abateu sobre a periferia da zona euro estão associados fenómenos como o desemprego, a precariedade, as desigualdades, a pobreza ou a conflitualidade (Standing, 2011; Campos Lima e Artiles, 2011; Costa, 2012a; Santos, 2012; Ferreira, 2012; Estanque, 2013; Estanque, Costa e Soeiro, 2013). Tomando por referência o caso português, procuramos neste texto situar o lugar do conflito, mais precisamente da greve, em contexto de austeridade. É nossa convicção que o potencial de contestação é significativo. Desde logo, porque são direitos laborais e sociais que estão a ser postos em causa, os quais se projetam muito para além da esfera socioprofissional, afetando as vidas das pessoas. Em todo o caso, e em aparente contradição com o incremento das razões para contestar, vivem-se tempos difíceis para mobilizar a "arma da greve", tanto mais que a austeridade tem o condão de levar muitos trabalhadores a recear que mais protesto possa significar maior risco de perda de emprego. 
Por outro lado, a crescente informalização e descontratualização das relações laborais, acentuada por sucessivas medidas e reformas políticas, coloca desafios e dificuldades à utilização deste instrumento.

No caso português, a austeridade resultante do Memorando de Entendimento celebrado em maio de 2011 entre o governo português e a Troika - constituída pelo Fundo Monetário Internacional (FMI), o Banco Central Europeu (BCE) e a Comissão Europeia (CE) -, bem como da atuação do governo português, refletiu-se na legislação laboral em vigor em Portugal desde agosto de 2012 (Lei 23/2012). De forma muito resumida, tais medidas traduzir-se-iam em pontos como: atribuição de maiores concessões à empresa sobre quem escolhe despedir em caso de extinção de posto de trabalho; despedimento por inadaptação mais abrangente; corte nas horas extraordinárias; banco de horas por negociação individual: redução nas indeminizações em caso de despedimento; redução de férias; corte nos feriados; possibilidade de encerramento das empresas nas pontes; regime de faltas alterado; redução de obrigações perante a inspeção do trabalho; possibilidade de trabalhar durante seis horas consecutivas (Costa, 2012b; Leite et al, 2013).

Estas reformas no mercado de trabalho parecem evidenciar que a austeridade está a reforçar as assimetrias nas relações laborais e a penalizar fortemente o "fator trabalho". O que, de resto, se refletiu não só no aumento de formas de emprego precário - que representam cerca de 30\% do emprego total, com incidência particular entre o grupo etário dos 15 aos 34 anos, onde atinge valores próximos dos $50 \%$ (Estanque e Costa, 2012) -, assim como nos números do desemprego, que em junho de 2013 atingiu mesmo os 17,4\% (sendo $12,1 \%$ na zona euro e $10,9 \%$ na UE/27), não obstante que em dezembro de 2013 se tenha registado uma descida para os 15,4\% (sendo 12,\% na zona euro e 10,9\% na UE/28) (Eurostat, 2014). ${ }^{1}$

Mas além destes, outros sinais perturbadores para as relações laborais decorrem das medidas de austeridade: perda de autonomia dos parceiros sociais, sobretudo dos sindicatos, que veem a sua posição ainda mais subalternizada; maior tensão nas relações entre os próprios atores das relações laborais (inclusive dentro do campo sindical); reforço das assimetrias no mercado de trabalho, designadamente entre classes de rendimentos elevados e classes de rendimentos baixos, ou na relação entre setor público e setor privado; forte diminuição do poder de compra das famílias; maior

\footnotetext{
${ }_{1}^{1}$ Ainda assim, importa recordar que a saída de pessoas em idade ativa do país e o aumento dos desencorajados, isto é, daqueles que deixaram ativamente de procurar emprego ajudem a perceber esse recuo do desemprego no último trimestre de 2013.
} 
empobrecimento do setor produtivo; não redução do défice de competitividade das empresas; menor controlo por parte da Autoridade para as Condições de Trabalho (ACT), uma vez que as empresas deixam de ser obrigadas a enviar à ACT o mapa do horário de trabalho ou o acordo de isenção de horário; etc. (Fernandes, 2012; Rebelo, 2012; Gomes, 2012; Costa, 2012b; Leite et al., 2013).

Qual é, neste contexto, o papel, a importância e as modalidades do exercício da greve? Sendo verdade que a greve funciona como a principal expressão do fenómeno da conflitualidade, os resultados das demandas sindicais (expressos em greves, por exemplo) tendem a arrastar-se no tempo, sendo isso, desde logo, mais evidente em contexto de crise e recessão (Hyman, 2012). De igual modo, "a frequência das greves e a participação dos trabalhadores nelas é mais uma medida da conflitualidade de um sistema de relações industriais do que da força sindical e só deve ser utilizada com reservas e em conjunto com a consideração de outras variáveis como uma medida da capacidade de mobilização sindical" (Stoleroff, 2013: 231).

Não deixando de ter em conta estas advertências, este texto divide-se em três partes. Na primeira suscitam-se alguns olhares sociológicos e cruzamentos analíticos sobre a greve. Na segunda parte valoriza-se um recorte quantitativo e procura-se apurar se o potencial teórico de conflitualidade se verifica em termos concretos. Por fim, relata-se uma experiência de greve de trabalhadores de um setor específico e precário - os trabalhadores da Linha Saúde 24 que permite avaliar em simultâneo os desafios que se colocam à ação sindical, bem como refletir sobre novas formas de organização do conflito social.

\section{Olhares sociológicos sobre a greve}

Uma análise sociológica da greve em contexto de austeridade (mas não só) é passível de incorporar vários olhares e, consequentemente, várias articulações.

a) Greve, democracia e regulação sociojurídica. Há mais de meio século, Lewis Coser (1956), ao cruzar análise de conflitos e estrutura social, considerava necessário distinguir os conflitos consoante estes ocorressem em sociedades democráticas ou autoritárias. Se um conflito ocorresse numa sociedade democrática tenderia a ser tolerado, o que no fundo permitia constatar que, enquanto direito democrático, o direito de greve estava (e está) conotado com a ideia de "liberdade de associação" (IUR, 2013:2). Por sua vez, ao ter lugar numa sociedade autoritária o conflito ou não seria permitido ou seria severamente reprimido.

As cinco greves gerais ocorridas em Portugal entre novembro de 2010 e junho de 2013 evidenciam, assim, que em contexto democrático o exercício 
da greve é reconhecido como direito elementar e crescentemente integrado em formas de regulação social. De resto, a ideia de "institucionalização dos conflitos" (Dahrendorf, 1981) ou das "válvulas de segurança" (Coser, 1956) está de certo modo corporizada na ideia do "pré-aviso". Ou seja, num contexto democrático a greve é regulada de forma positiva, de modo a ajustar as partes em confronto, de modo a não comprometer irremediavelmente à partida a relação entre essas partes. E, aliás, associada a essa ideia de regulação social positiva está uma dupla rejeição: de que se podem encontrar soluções definitivas para os conflitos; de que se resolvem conflitos com mais conflito/repressão. Daí os pressupostos para controlar positivamente os conflitos: i) inevitabilidade dos conflitos; ii) considerar que esta inevitabilidade não significa resignação; iii) importância do reconhecimento das diferenças entre as partes envolvidas (governo-sindicatos; sindicatos-patrões, etc.); iv) as organizações envolvidas representam interesses efetivos dos seus membros; v) importância fundamental de definir regras de procedimento que ajudem a diminuir as diferenças (Dahrendorf, 1981). No caso português, a definição de "serviços mínimos", apesar de poder não ser consensual e estar condicionada a decisões dos juízes dos colégios arbitrais, parece igualmente caminhar no sentido de um compromisso regulado para um grau mínimo de adaptação e integração das partes envolvidas (e da sociedade no seu todo), designadamente de antecipação/preparação face à ocorrência de uma greve, independentemente dos ganhos e perdas que dela possam decorrer para os vários protagonistas envolvidos.

Constata-se hoje, porém, que as dinâmicas da austeridade, com a crescente precarização das relações laborais, além de poderem paralisar, pelo medo, o recurso à greve, fazem também com que o exercício desta ressurja como ato "selvagem" e não reconhecido legalmente, como veremos no nosso estudo de caso. Num contexto de "desdemocratização da democracia" (Rosas, 2012), multiplicam-se as situações em que o exercício da greve é atirado para fora da regulação social, dado que o próprio trabalho é crescentemente empurrado para fora do contrato.

b) Ideologia(s), ação coletiva e consciência individual. Dir-se-á que a greve não é neutra, no sentido em que é condicionada por orientações ideológicas das organizações sindicais que a convocam. João Freire (2001), por exemplo, associa a capacidade mobilizadora do sindicalismo a um conjunto de ideologias: a reformista, também designada de trabalhista, nórdica, anglo-saxónica ou democrática, caracterizada pela defesa dos interesses imediatos dos trabalhadores e defendendo reformas na sociedade e no Estado no sentido de uma maior abertura democrática, nomeadamente pela articulação com partidos da área socialista; a sindicalista-revolucionária, caracterizada por 
ideias anarquistas ou libertárias, negando o papel dos partidos e propondo o movimento sindical como agente de uma transformação radical das sociedades capitalistas; e a bolchevista, teorizada a partir da revolução russa de 1917, inaugurando um novo modo de articulação da organização sindical ao partido político de vanguarda, que ficou conhecida pela expressão "correia de transmissão".

Ideologias convergentes ou próximas reúnem, assim, as condições para uma ação coletiva consistente, ainda que as políticas de austeridade (também elas ideologicamente orientadas) tenham tido o condão de aproximar, mesmo que por vezes apenas conjunturalmente, organizações sindicais com ideologias distintas. Isto é, a austeridade permitiu criar articulações em torno de interesses concretos, criando momentos de unificação de diferentes ideologias e correntes sindicais contra a ideologia do governo. Isso sucedeu, por exemplo, com a realização de três greves gerais conjuntas entre Confederação Geral dos Trabalhadores Portugueses (CGTP) e União Geral de Trabalhadores (UGT), como é sabido duas organizações guiadas por orientações ideológicas conflituantes. Tal sucedeu com as greves gerais de 24.11.2010 (contra os anunciados cortes entre 3,5\% e 10\%, a partir de janeiro de 2011, dos salários dos funcionários públicos com rendimentos acima de 1500 euros), de 24.11.2011 (contra os cortes dos subsídios de férias e natal aos funcionário públicos em 2012, assim como da sobretaxa de 50\% em sede de IRS do subsídio de Natal) e em 28.06.2013 (em resultado dos cortes previstos no Documento de Estratégia Orçamental e, portanto, das medidas associadas à reforma do Estado: reforma aos 66 anos; prolongamento do horário da função pública das 35 para 40 horas semanais; redução de férias; aumento das contribuições para a ADSE; redução de 30000 funcionários públicos; regime de mobilidade especial, etc.). Ainda assim, noutros momentos, a tensão entre centrais sindicais sobressaiu. ${ }^{2}$

Mas mesmo que a ação coletiva "finte" a ideologia, a decisão de fazer greve não deixa de ser também individual. Embora a convocação de uma greve resulte de uma decisão legitimada pelo coletivo, com base no consenso dado pelos associados de uma determinada associação sindical e não

\footnotetext{
${ }^{2}$ Só em 2012 isso ocorreu por duas vezes: com a greve geral de 22.03.2012, convocada pela CGTP em resposta à assinatura do acordo de concertação social (intitulado Compromisso para o crescimento e emprego) celebrado entre o governo, as confederações patronais e a UGT em 18.01.2012; e com a greve geral de 14.11.2012, por sinal uma greve sindical ibérica promovida pela Confederação Europeia de Sindicatos (CES), e que em Portugal, apesar de convocada apenas pela CGTP, envolveu a CES e mais 30 sindicatos da UGT. No caso português, registe-se ainda que esta greve geral surgiu como reação à proposta de Orçamento de Estado para 2013, que implicou um brutal aumento da carga fiscal.
} 
apenas pelos órgãos de direção, a decisão de fazer ou não fazer greve é, afinal, da responsabilidade de cada cidadão/ã. Aliás, Mancur Olson (1998), ao reportar-se ao paradoxo da ação coletiva, considerou que a mobilização dos atores individuais para a obtenção de bens coletivos (por exemplo um bem em que todo o grupo está interessado e cujo usufruto não se encontra vedado a qualquer membro do grupo) está sujeita à intervenção da racionalidade (e do egoísmo) do ator individual. Assim, sempre que alguém hesita fazer greve por ser incapaz de superar o desafio de "vencer o medo" (Silva, 2012), porque afinal fazer greve significa perda de salário e pode igualmente significar perda de emprego, não está necessariamente contra o ato coletivo de fazer greve mas a ponderar interesses próprios. No caso que analisaremos adiante, esta tensão emerge de forma evidente.

c) Escalas, controvérsias e modalidades. A escala em que as greves são mais frequentes é a nacional, por sinal onde salários, condições de trabalho e regimes jurídicos são definidos e, portanto, passíveis de discordância e contestação. É, aliás, uma escala que não está imune a controvérsias públicas: geralmente entre os que questionam a oportunidade da greve e/ou duvidam da sua eficácia e os que entendem que recusar hoje a luta é caucionar o retrocesso imposto pelas políticas governamentais. Os focos de controvérsia têm até por vezes o condão de recentrar e análise do conflito e fazer com que a discussão do que está em jogo seja posta em causa quando (de parte a parte) há acusações que referem que se está a desvirtuar o foco do conflito prejudicando terceiros (nomeadamente a ideia de que uma greve dos professores aos exames/avaliações prejudica os alunos que nada têm que ver com o assunto, ou a ideia de que uma greve dos enfermeiros tem como principais "vítimas" os utentes). A situação inversa também é equacionável quando o suposto prejuízo para uns pode significar benefício para outros: por exemplo, uma greve de transportes públicos pode ser penalizadora para utentes que deles se servem e ao mesmo tempo ser benéfica para os taxistas que, assim, poderão ter mais clientes.

Sendo certo que o espaço público e o espaço mediático se estruturam ainda dominantemente à escala nacional (desde logo pela questão da língua e da identificação em torno de comunidades políticas nacionais), uma greve transnacional (envolvendo vários países e estruturas sindicais) teria certamente uma outra visibilidade e um outro impacto. Porém, no contexto europeu e mundial, é raro falar-se em "greve europeia/mundial" (Costa, 2008; 2010). ${ }^{3}$ E embora o Tribunal de Justiça da União Europeia,

\footnotetext{
3 Em todo o caso, vale a pena assinalar a importância crescente dos protestos mundiais, no seio dos quais a "antiausteridade" ocupa lugar de destaque (Ortiz et al., 2013).
} 
a propósito dos casos Viking e Laval, ${ }^{4}$ tenha explicitamente reconhecido o direito à greve com um direito fundamental protegido por legislação da UE e internacional (pelos padrões da Organização Internacional do Trabalho), a interpretação sobre o modo como esse direito poderia ser exercido no mercado interno da UE acabou por conceder primazia às liberdades económicas fundamentais. Com efeito, o direito à greve foi visto como uma restrição às liberdades económicas que apenas poderia ser justificado em casos individuais e dentro de um enquadramento interpretativo de estrita condicionalidade e proporcionalidade (Brunn, 2013: 8; Giubboni e O'Brien, 2009: 9-10).

Por outro lado, além das escalas e das controvérsias e obstáculos sociojurídicos que lhes estão associados - e que apontam por vezes para uma certa marginalização da greve (Giraud, 2005) -, importa situar as modalidades da greve. Já aqui nos reportámos à ideia de "greve geral", um tipo de greve que é suposto agregar a indignação de toda a sociedade. Mas é importante mencionar também as greves de âmbito setorial (como por exemplo greves no setor dos transportes, muito diretamente afetado também por cortes salariais ou processos de privatização) ou greves setoriais protagonizadas por categoriais socioprofissionais afetadas pela austeridade (como o caso dos professores ou dos enfermeiros). Muitas vezes, tais protestos setoriais e socioprofissionais acabam por ter também um alcance nacional e extensível a todo o país - como foi por exemplo o caso da greve dos professores às avaliações e exames, em resultado do aumento do horário de trabalho das 35 para as 40 horas no setor público, ou do regime de mobilidade (requalificação) - mesmo que também tenha sido frequente em Portugal nos últimos três anos o recurso à modalidade de "greve parcial" (muitas vezes coincidindo com momentos de "hora de ponta"), por sinal uma modalidade que em parte se explicará como forma de não pesar tanto sobre os bolsos de quem faz greve, tanto mais que não há em Portugal tradição de "fundos de greve" .

A relação entre setor público e setor privado perpassa também as modalidades de greve. Sobretudo quando a greve se diz "geral", é suposto que ela abarque tanto o setor público como o privado. Dir-se-á que o ato de

\footnotetext{
${ }^{4}$ Cujas sínteses podem ser consultadas em http://www.etuc.org/r/848 e http://www.etuc. org $/ \mathrm{r} / 847$.

5 Trata-se de uma prática mais comum nos sindicatos escandinavos ou alemães, ao passo que em Portugal poucos sindicatos (como os de maquinistas da CP, por exemplo) recorrem a ela. E uma explicação plausível para isso prende-se com razões económicas (por exemplo, os salários baixos praticados em Portugal tornam pouco viável que o trabalhador desconte uma percentagem adicional além da quota mensal descontada para o sindicato).
} 
fazer greve envolve tradicionalmente um maior sentimento de medo e insegurança entre os que trabalham no setor privado do que os que o fazem no setor público, o que em parte explica, de acordo com o estudo de Rebelo e Brites (2012: 74), também que o peso maior (40,1\%) de quem fez greve se encontra na administração pública. No entanto, como os funcionários públicos têm sido severamente atingidos pelas medidas da austeridade, não surpreende que o receio de perda de vínculo ao Estado seja acompanhado por um receio por parte daqueles de participar em greves.

d) Temporalidades e resultados. A greve cruza-se com a dimensão temporal não só no "antes", mas também no "durante" e no "depois". O grau de definição dos objetivos visados com a greve remete-nos para as razões que justificam a greve. Retomando Lewis Coser (1956), estamos por vezes diante de uma tensão entre objetivos alcançáveis e não alcançáveis e a expressão da greve (quer no "durante" e no "depois") é guiada por essa tensão. Segundo Coser, quando os conflitos são realísticos, ou seja, assentes em resultados alcançáveis, isso permite que se definam alternativas quanto aos meios para visar certos objetivos. Por outro lado, quando o conflito se apoia em objetivos não alcançáveis, então tende a radicalizar-se a relação entre os antagonistas e o envolvimento emocional, traduzido em ataques entre os antagonistas, pode mesmo despontar.

A duração da greve traduz greve a acontecer. Em Portugal são comuns jornadas de luta de um dia (como tem sucedido com as greves gerais), ainda que as greves possam prolongar-se por uma semana ou duas semanas, dependendo dos setores de atividade. Não havendo, como se deu conta, tradição de "fundo de greve" em Portugal, a sua maior duração poderá estar dependente da capacidade criativa dos protagonistas para "aguentar" o conflito. ${ }^{6}$

Mas o "pós-greve" (o "depois") é talvez o momento mais importante de uma conceção da greve enquanto processo. E é-o no sentido em que aponta para impactos, eficácia, resultados e, portanto, permite ponderar o grau de alcance (ou não) dos objetivos visados pela greve. $\mathrm{Na}$ verdade,

\footnotetext{
${ }^{6}$ Em junho de 2013, a greve dos professores do ensino secundário foi convocada para ocorrer durante um período de duas semanas, facto que obrigou os docentes a organizarem-se para não sofrerem mais penalizações salariais, designadamente contribuindo para "fundos de maneio". Assim, de entre a lista dos docentes que se declararam disponíveis para aderir à greve foi acordado que em cada conselho de turma na escola onde era suposto atribuir avaliações aos alunos, faltasse pelo menos um professor, o que inviabilizava a realização da reunião. Desse modo, com o fundo de maneio (contribuições de 10 euros por professor em greve, mas incluindo o de alguns não grevistas), os docentes que decidiram aderir à paralisação receberam uma "compensação solidária" que minimizou, no final do mês, o impacto da perda de salário correspondente às horas de greve (Diário de Notícias, 13.03.2013).
} 
como essência do poder sindical (IUR, 2013: 2), o exercício do direito de greve ao longo de muitas décadas traduziu-se em múltiplas conquistas e avanços civilizacionais quer do ponto de vista das condições de trabalho (redução de horários, articulação trabalho/vida familiar, defesa dos postos de trabalho, proibição de despedimento sem justa causa), quer do ponto de vistas das retribuições pecuniárias (instituição de um salário mínimo nacional; aumentos salariais substanciais; um mês de férias pagas com respetivo subsídio; $13 .^{\circ}$ e $14 .^{\circ}$ mês), etc. No fundo, trata-se de "agir contra a corrente", de "agir para transformar" (Silva, 2002) com o intuito de "obter benefícios e concessões" (Dias, 2012: 114).

Não obstante reportarmo-nos, na secção seguinte, à expressão quantitativa das greves, os resultados de uma greve estão longe de se medir apenas por um critério quantitativo, assente na simples resposta à questão: "qual foi a taxa de adesão?”. Sendo certo que a resposta a esta pergunta é essencial - tanto mais que se destina a medir o impacto imediato da greve -, não é menos verdade, como se sabe, que tal medição é suscetível de vários enviesamentos e tensões entre argumentos políticos e técnicos entre as partes em confronto. Assim sendo, consideramos que a greve pode produzir resultados que vão além dos impactos imediatos, até porque as próprias controvérsias em torno da "eficácia" ou do carácter "inócuo" das greves não ficam resolvidas no dia seguinte (Estanque, 2010). No fundo, os resultados das greves devem ser analisados à luz do grau de alcance dos objetivos (de ambas as partes), o que pode suceder no curto, médio ou longo prazo (Costa, 2011).

O facto de, em muitas situações, não transparecer para a opinião pública uma ideia de objetivos/resultados cumpridos de modo imediato pode criar uma certa descrença na greve enquanto arma de luta a médio/longo prazo. Voltando ao estudo de Rebelo e Brites (2012: 75-77), constata-se o seguinte face à pergunta "Que resultados obteve da última vez que fez greve?": para $51,5 \%$ (dos 369 inquiridos) a resposta é "nenhuns"; para 32,5\% foram alcançados resultados "parciais"; apenas 6,5\% se declararam inteiramente satisfeitos por terem conseguido resultados "totais". Esta visão pragmática e pouco otimista sobre a eficácia das greves parece mesmo contagiar os discursos das lideranças sindicais menos habituadas a colocar a greve à frente da negociação. ${ }^{7} \mathrm{O}$ que pode também ser visto não só como um recuperar do viés ideológico que perpassa os discursos sindicais, bem como mais um reflexo dos efeitos perversos das políticas de austeridade.

\footnotetext{
${ }^{7} \mathrm{Na}$ verdade, o atual líder da UGT, por mais de uma vez aludiu em público ao "caso grego" para sustentar que, naquele país, nos últimos 3-4 anos mais de 20 greves gerais foram realizadas sem terem produzido resultados concretos.
} 


\section{Expressão quantitativa das greves}

Já se disse que a greve se inscreve no repertório histórico de ação coletiva do sindicalismo. Por outro lado, também já se advertiu que a greve, por si só, não constitui um indicador de força ou de capacidade de mobilização sindical. E, aliás, a força sindical é "determinada pela capacidade das organizações sindicais (confederativas e sectoriais ou locais) em mobilizar vários tipos de recursos e obter parcial ou inteiramente os seus objetivos. Assim, o conceito é composto tanto por indicadores quantitativos como qualitativos e refere-se inter alia aos recursos organizacionais, nomeadamente a sindicalização, o desenvolvimento da organização sindical, a influência dos sindicatos junto dos partidos políticos e do Estado, os seus aliados, bem como às capacidades mobilizadoras dos sindicalizados e demais trabalhadores, ao poder negocial dos sindicatos e ao grau de institucionalização obtido pelos sindicatos num sistema de regulação socioeconómico, de que a extensão/cobertura e efetividade da contratação coletiva e a concertação social são dimensões importantes" (Stoleroff, 2013: 224).

$\mathrm{Na}$ base da força sindical está a sindicalização, ou seja, o número absoluto de sócios de um sindicato, bem como a densidade sindical num dado setor (coeficiente entre o número de sindicalizados e de trabalhadores assalariados no mesmo setor). Estes constituem elementos centrais para aferir da representatividade e da influência dos sindicatos no campo das relações coletivas de trabalho, na sua relação com outros atores sociais e políticos, mas igualmente na sociedade em geral (Pedersini, 2010). Mas mesmo não sendo a sindicalização o único critério para aferir da influência social dos sindicatos, ela é um dos seus recursos fundamentais (Sousa, 2011: 5), pois da sua força organizacional dependerá a capacidade de envolver o maior número possível de membros na atividade quotidiana da organização, de assumir tarefas de representação nas mais diversas instâncias, bem como a prossecução dos seus objetivos, através da mobilização e da conquista do apoio dos trabalhadores em geral. E, naturalmente, as quotizações dos sócios constituem a principal fonte de receita das organizações sindicais, das quais dependem os meios e recursos necessários à sua atividade. Tal é ainda mais notório em países onde não existe qualquer tipo de subvenção estatal aos sindicatos, como é o caso português.

Embora não exista uma relação de causalidade entre sindicalização e número de greves, esta primeira é uma condição propiciadora de uma maior capacidade de mobilização coletiva e, como tal, do potencial recurso à greve. É por isso que, num primeiro momento, reconstituímos, com base na informação disponível, uma série estatística longa das greves em Portugal mas também um indicador de força sindical que é a densidade sindical. 
Posteriormente, concentra-se a análise sobre o período mais recente, de 2007 em diante, tentando desde logo perceber se se verificou um aumento do número de greves oficiais ${ }^{8}$, quais os setores que mais se mobilizam, a sua "agenda de reivindicações" e a sua eficácia.

\section{QUADRO 1 - Sindicalização ${ }^{9}$ e greves em Portugal: 1974-2012}

\begin{tabular}{|c|c|c|c|c|}
\hline Ano & $\begin{array}{l}\text { N. }{ }^{\circ} \text { sindicalizados } \\
\text { (milhares) }\end{array}$ & $\begin{array}{c}\text { Densidade sindical } \\
(\%)\end{array}$ & $\mathrm{N} .^{\circ}$ greves & $\begin{array}{l}\text { N. }{ }^{\circ} \text { trabalhadores em } \\
\text { greve (milhares) }\end{array}$ \\
\hline 1974 & --- & --- & 313 & --- \\
\hline 1975 & --- & --- & 340 & --- \\
\hline 1976 & --- & --- & 367 & --- \\
\hline 1977 & --- & --- & 357 & --- \\
\hline 1978 & 1486,8 & 60,8 & 333 & --- \\
\hline 1979 & 1500 & 60,1 & 381 & --- \\
\hline 1980 & 1460 & 54,8 & 374 & --- \\
\hline 1981 & 1420 & 53,5 & 756 & --- \\
\hline 1982 & 1380 & 50,5 & 563 & --- \\
\hline 1983 & 1340 & 47,2 & 532 & --- \\
\hline 1984 & 1300 & 47,2 & 550 & --- \\
\hline 1985 & 1225 & 44,6 & 504 & --- \\
\hline $1986^{1}$ & 1150 & 41,2 & 363 & 231,5 \\
\hline 1987 & 1093 & 38,6 & 213 & 81,3 \\
\hline 1988 & 1035 & 35 & 181 & 155,5 \\
\hline 1989 & 978 & 32 & 307 & 296,1 \\
\hline
\end{tabular}

cont.

\footnotetext{
${ }^{8}$ Uma greve é convocada nos termos dispostos nos artigos 530. a 543. ${ }^{\circ}$ do Código do Trabalho. Para efeitos estatísticos, "considera-se greve, em sentido amplo, a abstenção ou perturbação temporária e concertada dos termos normais de prestação de trabalho por parte de um grupo de trabalhadores, tendo em vista forçar as entidades empregadoras ou os poderes públicos à aceitação das suas reivindicações" (GEE/Ministério da Economia, 2011). No entanto, os dados disponíveis compreendem apenas paralisações durante o período normal de trabalho. Não incluem outros tipos de greve, nomeadamente às horas extraordinárias e trabalho suplementar, embora haja recolha de informação sobre estas (GEP/MTSS, 2008).

9 Em Portugal, além das contribuições dos anos 90 de Conceição Cerdeira, Edite Padilha, Alan Stoleroff e Reinhard Naumann sobre a filiação sindical, esta temática não foi objeto de tratamento alargado. Para uma explicação de tal realidade, ver Sousa (2011). A informação sobre o número de sindicalizados e densidade sindical são retirados da base de dados ICTWSS - Database on Institutional Characteristics of Trade Unions, Wage Setting, State Intervention and Social Pacts, compilada por Jelle Visser (ver ICTWSS, 2014). Não existe informação disponível para 2011 e 2012.
} 
184 | Hermes Augusto Costa, Hugo Dias, José Soeiro

cont.

\begin{tabular}{|c|c|c|c|c|}
\hline Ano & $\begin{array}{l}\mathrm{N} .^{\circ} \text { sindicalizados } \\
\text { (milhares) }\end{array}$ & $\begin{array}{c}\text { Densidade sindical } \\
(\%)\end{array}$ & $\mathrm{N} .^{\circ}$ greves & $\begin{array}{c}\mathrm{N} .^{\circ} \text { trabalhadores em } \\
\text { greve (milhares) }\end{array}$ \\
\hline 1990 & 920 & 28 & 271 & 128,9 \\
\hline 1991 & 896 & 28,2 & 262 & 119,1 \\
\hline 1992 & 872 & 26,1 & 409 & 131,9 \\
\hline 1993 & 848 & 26,1 & 230 & 83,1 \\
\hline 1994 & 824 & 25,9 & 300 & 94,4 \\
\hline $1995^{2}$ & 800 & 25,4 & 282 & 60,4 \\
\hline 1996 & 802,6 & 25,5 & 272 & 50,5 \\
\hline 1997 & 805,1 & 25,2 & 265 & 45,8 \\
\hline 1998 & 798 & 23,4 & 227 & 44,2 \\
\hline 1999 & 790 & 22,5 & 200 & 33,5 \\
\hline 2000 & 783 & 21,6 & 250 & 38,8 \\
\hline 2001 & 824 & 22,4 & 208 & 26,1 \\
\hline 2002 & 768 & 20,7 & 250 & 80,2 \\
\hline 2003 & 783,4 & 21,2 & 170 & 30,3 \\
\hline 2004 & 802,6 & 21,4 & 122 & 31,9 \\
\hline 2005 & 804,2 & 21,2 & 126 & 21,7 \\
\hline 2006 & 805,9 & 20,8 & 155 & 33,5 \\
\hline 2007 & 804,4 & 20,8 & 99 & 29,2 \\
\hline $2008^{3}$ & 803 & 20,5 & --- & --- \\
\hline 2009 & 771 & 20,1 & --- & -- \\
\hline 2010 & 738 & 19,3 & 131 & 72,3 \\
\hline 2011 & -- & --- & 106 & 59 \\
\hline 2012 & --- & --- & 147 & 93,1 \\
\hline
\end{tabular}

${ }^{1}$ A série cronológica a partir de 1986 abrange todos os setores de atividade económica, à exceção da Administração Pública (GEP/MTSS, 2008).

2 A partir de 1995, a série cronológica abrange o Continente e as Regiões Autónomas (GEP/MTSS, 2008).

${ }^{3}$ Em 2008 e 2009 não foram produzidas estatísticas, por insuficiente informação recolhida (GEE/ Ministério da Economia, 2011). Existem no entanto dados disponíveis para as Regiões Autónomas dos Açores e da Madeira.

Fontes: GEP/MTSS, 2008; GEE/Ministério da Economia, 2011, 2012, 2013; ICTWSS, 2013 Observatório do Emprego e Formação Profissional, Região Autónoma dos Açores (2011, 2012, 2013); Secretaria Geral da Educação e Recursos Humanos, Região Autónoma da Madeira (2014); Stoleroff (2013).

Da análise do Quadro 1 pode constatar-se uma tendência longa de decréscimo, quer dos indicadores de filiação e densidade sindical, quer das 
estatísticas da greve, apesar da existência de alguns períodos de inflexão ou abrandamento dessa tendência.

O período de maior capacidade de mobilização e ação coletiva, sob a influência de um discurso classista que advogava a superação do capitalismo, ocorre na segunda metade da década de 1970, quando na Europa a concertação social tripartida era já a regra (Santos, 2004: 161-162). O número de sindicalizados e a densidade sindical atingem os valores mais elevados (60,8\% em 1978), uma herança parcial da sindicalização obrigatória do Estado Novo, mas também um elevado número de greves (367 em 1976). Em meados dos anos 80, inicia-se um processo paulatino de decréscimo da sindicalização enquanto a atividade grevista atinge níveis elevados (756 greves em 1981). Até ao início dos anos 80 foram desenvolvidas lutas para o estabelecimento da contratação coletiva, processo esse que continuou no início da década de 80 e que manteve a conflitualidade, mas com uma intensidade menor. Desde o início dos anos 80 até 1985, as greves expressaram lutas para defender as "conquistas de Abril" e desestabilizar os governos da direita e do bloco central (Stoleroff, 2013: 231).

No que diz respeito à sindicalização, após um decréscimo acentuado na década de 80 (de 54,8\% em 1980 para 32\% em 1989), essa quebra persiste na década de 90 , embora de forma menos acentuada. Neste processo verificou-se uma alteração da composição sociológica da sindicalização. À diminuição dos setores da indústria correspondeu um aumento do peso de empregados no setor dos serviços, nomeadamente da Administração Central e Local (MTSS, 2006: 68), contingente esse que impediu uma quebra mais acentuada dos níveis de sindicalização.

A data de entrada na Comunidade Económica Europeia, que coincide grosso modo com a institucionalização da concertação social com a participação dos sindicatos, marca uma tendência forte de decréscimo do número de greves (apenas invertida em 1989, com 307 greves e 296000 grevistas), até atingir um mínimo histórico de 99 greves em 2007, envolvendo cerca de 29200 trabalhadores.

Neste contexto, uma hipótese a explorar prende-se com a possibilidade de esta tendência decrescente se ter invertido no período mais recente, mesmo que de forma temporária, como expressão - não a única, mas sem dúvida relevante - do conflito sociolaboral em torno das medidas implementadas nos sucessivos pacotes de austeridade. A ausência de dados disponíveis para 2008 e 2009 impede a possibilidade de acompanhar a evolução ao longo de todo o período recente, quando a crise financeira internacional começava já a produzir efeitos de contágio nas dívidas soberanas, e as medidas de 
restrição orçamental e de transformação da regulação laboral se começaram a fazer sentir em países como Portugal.

Deste modo, se tivermos em consideração a informação disponível para os anos de 2010, 2011 e 2012, verifica-se de facto uma inversão do valor mínimo registado, quer em número de greves, quer em número de trabalhadores em greve. Assim, em 2010, o número de trabalhadores em greve aumenta, em relação a 2007, para cerca de 72 300; em 2011 desce para valores próximos de 59 000; mas regista uma grande subida em 2012, ano em que foram contabilizados cerca de 93 100, valor mais elevado desde 1994.

Em primeiro lugar, é de assinalar que houve neste período (2010-2012) quatro greves gerais convocadas pela CGTP, duas delas em conjunto com a UGT, com pré-avisos de greve que cobriram todos os setores de atividade económica. Em segundo lugar, e conforme se pode observar no Quadro 2, os setores que mais se destacam em termos de atividade grevista são, em números absolutos e por ordem crescente, as atividades de saúde humana e apoio social ( 2010 - 6949; 2011 - 6822; 2012 - 14 342), Indústrias transformadoras (2010 - 22 802; 2011 - 14 781; 2012 - 21 875) e Transportes e armazenagem (2010 - 26 189; 2011 - 21 193; 2012 - 35 519). Se se considerar o critério da taxa de trabalhadores em greve por 1000 trabalhadores por conta de outrem (TCO), os transportes e a armazenagem assumem uma posição de indiscutível destaque, com 204,2 em 2010, 168 em 2011 e 281 em 2012.

QUADRO 2 - Greves por setor de atividade, 2010-2012 ${ }^{10}$

\begin{tabular}{|c|c|c|c|c|c|c|c|c|c|}
\hline \multirow[t]{2}{*}{$\mathrm{CAE} / \mathrm{Rev} \mathbf{3}^{1}$} & \multicolumn{3}{|c|}{2010} & \multicolumn{3}{|c|}{2011} & \multicolumn{3}{|c|}{2012} \\
\hline & 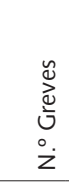 & 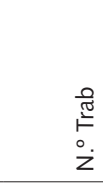 & 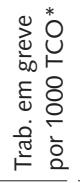 & 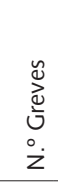 & $\begin{array}{l}\dot{0} \\
\stackrel{\tilde{\pi}}{=} \\
\circ \\
\dot{z}\end{array}$ & 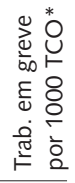 & 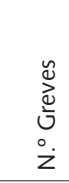 & 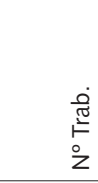 & 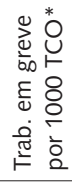 \\
\hline Total & 123 & 70792 & 27,3 & 88 & 58413 & 23 & 127 & 92324 & 36 \\
\hline $\begin{array}{l}\text { A - Agricultura, } \\
\text { caça, silvicultura } \\
\text { e pesca }\end{array}$ & 1 & 224 & 4,6 & 1 & 87 & 2 & 3 & 265 & 5 \\
\hline $\begin{array}{l}\text { B - Indústrias } \\
\text { extrativas }\end{array}$ & 5 & 515 & 52,3 & 2 & 68 & 7 & 3 & 92 & 10 \\
\hline $\begin{array}{l}\mathrm{C}-\text { Indústrias } \\
\text { transformadoras }\end{array}$ & 55 & 22802 & 39,5 & 31 & 14781 & 26 & 50 & 21875 & 39 \\
\hline
\end{tabular}

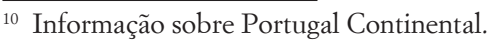


cont.

\begin{tabular}{|c|c|c|c|c|c|c|c|c|c|}
\hline \multirow[t]{2}{*}{ CAE/Rev. $3^{1}$} & \multicolumn{3}{|c|}{2010} & \multicolumn{3}{|c|}{2011} & \multicolumn{3}{|c|}{2012} \\
\hline & 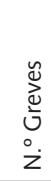 & $\begin{array}{l}\frac{0}{\pi} \\
\stackrel{5}{\models} \\
\circ \\
z\end{array}$ & 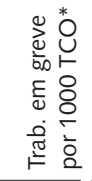 & 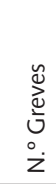 & $\begin{array}{l}\frac{\dot{\pi}}{\sqrt{2}} \\
\stackrel{\circ}{\circ} \\
\dot{z}\end{array}$ & 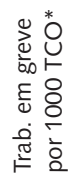 & 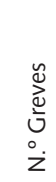 & $\begin{array}{l}\dot{0} \\
\stackrel{0}{\frac{\pi}{2}} \\
\dot{\circ}\end{array}$ & 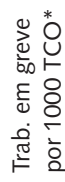 \\
\hline $\begin{array}{l}\text { D - Eletricidade, } \\
\text { gás, vapor e } \\
\text { água }\end{array}$ & 4 & 665 & 90,2 & 4 & 529 & 74 & 5 & 613 & 86 \\
\hline $\begin{array}{l}\text { E - Captação., } \\
\text { tratamento, } \\
\text { distribuição de } \\
\text { água }\end{array}$ & 6 & 1199 & 61,2 & 5 & 992 & 50 & 4 & 1343 & 67 \\
\hline F - Construção & 6 & 321 & 1,2 & 4 & 257 & 1 & 3 & 209 & 1 \\
\hline $\begin{array}{l}\mathrm{G}-\text { Comércio } \mathrm{p} / \\
\text { grosso e retalho }\end{array}$ & 16 & 2069 & 4,1 & 9 & 2412 & 5 & 17 & 2933 & 6 \\
\hline $\begin{array}{l}\mathrm{H} \text { - Transportes } \\
\text { e armazenagem }\end{array}$ & 43 & 26189 & 204,2 & 51 & 21193 & 168 & 62 & 35519 & 281 \\
\hline $\begin{array}{l}\text { I- Alojamento, } \\
\text { restauração e } \\
\text { similares }\end{array}$ & 11 & 1149 & 6,4 & 11 & 850 & 5 & 11 & 1006 & 6 \\
\hline $\begin{array}{l}\text { J - Atividades de } \\
\text { informação e } \\
\text { comunicação }\end{array}$ & 4 & 1534 & 25,2 & 6 & 1154 & 18 & 12 & 2195 & 35 \\
\hline $\begin{array}{l}\mathrm{K}-\text { Atividades } \\
\text { financeiras e } \\
\text { seguros }\end{array}$ & 4 & 1638 & 18,8 & 4 & 3508 & 41 & 5 & 4767 & 56 \\
\hline $\begin{array}{l}\text { L-Atividades } \\
\text { imobiliárias }\end{array}$ & 1 & 25 & 1,4 & 1 & 40 & 2 & 2 & 38 & 2 \\
\hline $\begin{array}{l}\text { M-Atividades } \\
\text { de consultadoria, } \\
\text { científicas e } \\
\text { técnicas }\end{array}$ & 6 & 259 & 2,6 & 6 & 225 & 2 & 10 & 404 & 4 \\
\hline $\begin{array}{l}\mathrm{N} \text { - Atividades } \\
\text { administrativas, } \\
\text { serviços de apoio }\end{array}$ & 9 & 1935 & 8,1 & 11 & 2352 & 10 & 9 & 3194 & 14 \\
\hline P - Educação & 5 & 943 & 17 & 2 & 958 & 17 & 4 & 1333 & 24 \\
\hline $\begin{array}{l}\text { Q - Atividades de } \\
\text { saúde humana e } \\
\text { apoio social }\end{array}$ & 7 & 6949 & 35,7 & 6 & 6822 & 33 & 13 & 14342 & 69 \\
\hline $\begin{array}{l}\mathrm{R} \text { - Atividades } \\
\text { artísticas, } \\
\text { espetáculos e } \\
\text { desporto }\end{array}$ & 7 & 437 & 20,9 & 5 & 385 & 19 & 9 & 628 & 30 \\
\hline $\begin{array}{l}\mathrm{S}-\text { Outras } \\
\text { atividades e } \\
\text { serviços }\end{array}$ & 9 & 1939 & 28 & 8 & 1800 & 26 & 11 & 1568 & 22 \\
\hline
\end{tabular}

${ }^{1}$ Classificação Portuguesa de Atividades Económicas, Revisão 3.

Fonte: GEE/Ministério da Economia (2011, 2012, 2013). 
Por fim, convém enfatizar que a informação disponível sobre as greves, a partir de 1986, compreende apenas o setor privado. Assim, e tendo em conta a alteração da composição sociológica da sindicalização acima referenciada, e a elevada conflitualidade laboral (recente) no setor da Administração Pública, Central e Local, pode-se afirmar que as estatísticas das greves se encontram amplamente subavaliadas (Gall, 2012). Embora não exista uma série estatística para as greves no setor público, a informação parcelar disponibilizada pela Direção Geral da Administração e do Emprego Público ${ }^{11}$ para o período de 2007-2012 permite corroborar essa afirmação.

Tomando o ano de 2007 como exemplo (Quadro 3), da qual existem registos de quatro greves abrangendo trabalhadores da administração direta e indireta do Estado, vulgo Administração Central, contabilizam-se 128578 grevistas, mais do quádruplo do número para o mesmo ano de todo o setor privado. $\mathrm{O}$ mesmo exercício poderá ser feito para o período posterior de 2010-2012. Mais uma vez, se nos ativermos à informação disponível no Quadro 3 constatamos que o contingente de funcionários públicos da Administração Central é extremamente significativo, em comparação com o número de trabalhadores em greve da totalidade dos setores privados de atividade económica.

QUADRO 3 - Mapas de adesão à greve, 2007/2013

Administração direta e indireta do Estado

\begin{tabular}{cccc}
\hline Greve & $\begin{array}{c}\text { Trabalhadores } \\
\text { abrangidos }\end{array}$ & Trabalhadores em greve & Percentagem \\
\hline 30.05 .07 & 344876 & 48103 & 13,95 \\
\hline 12.07 .07 & 200155 & 1927 & 0,96 \\
\hline 18.10 .07 & 267411 & 8281 & 3,1 \\
\hline
\end{tabular}

cont.

\footnotetext{
${ }^{11}$ A 15 de maio de 2007 um despacho sem número assinado pelo então Ministro das Finanças e da Administração Interna, Fernando Teixeira dos Santos, instituiu procedimentos de recolha e de divulgação de informação sobre a adesão à greve dos trabalhadores da Administração Central do Estado. Este procedimento é reafirmado pelo novo governo, formado após as eleições legislativas de 5 de junho de 2011, através do despacho n. ${ }^{\circ}$ 343/11/MEF, de 20 de outubro de 2011. O Despacho n. ${ }^{\circ}$ 1034/2012, de 16 de março de 2012, do Secretário de Estado da Administração Pública, Hélder Rosalino, descontinuou esses mesmos procedimentos, que são retomados através do Despacho n. ${ }^{\circ}$ 3876/2012, de 12 de novembro de 2012, do mesmo Secretário de Estado. Assim, a informação disponível não é exaustiva no período em causa e abrange apenas a administração direta e indireta do Estado (DGAEP, 2014). Não existe informação disponível compilada para a Administração Local.
} 
cont.

\begin{tabular}{cccc}
\hline Greve & $\begin{array}{c}\text { Trabalhadores } \\
\text { abrangidos }\end{array}$ & Trabalhadores em greve & Percentagem \\
\hline 30.11 .07 & 321049 & 70267 & 21,89 \\
\hline 14.03 .08 & 353911 & 29620 & 8,37 \\
\hline 01.10 .08 & 281314 & 30237 & 10,75 \\
\hline 21.11 .08 & 209452 & 8404 & 4,01 \\
\hline 04.03 .10 & 419075 & 61965 & 14,79 \\
\hline 24.11 .10 & 425877 & 121833 & 28,61 \\
\hline 14.11 .12 & 334436 & 70072 & 21 \\
\hline 27.07 .13 & 309961 & 63536 & 20,5 \\
\hline 08.11 .13 & 292005 & 67102 & 23 \\
\hline
\end{tabular}

Fonte: DGAEP, 2014

O aumento do número de greves e de trabalhadores em greve não corresponde, no entanto, a uma maior eficácia na obtenção de resultados. No Quadro 4, que compila informação das reivindicações por resultado alcançado, pode-se observar que a esmagadora maioria das reivindicações que deram origem a greves e plasmadas nos seus pré-avisos foram recusadas. O ano de 2012 é particularmente emblemático, pois apesar do aumento significativo do número de greves e trabalhadores em greve, acima identificado, apenas 4,6\% das reivindicações foram aceites, 8,6\% parcialmente aceites e $86,7 \%$ recusadas. O que, de resto, parece corroborar a visão expressa por quem faz greve e a que anteriormente aludimos com base no estudo de Rebelo e Brites (2012).

QUADRO 4 - Reivindicações por resultado alcançado, 2007-2012

\begin{tabular}{lcccc}
\hline Ano & $\mathbf{2 0 0 7}$ & $\mathbf{2 0 1 0}$ & $\mathbf{2 0 1 1}$ & $\mathbf{2 0 1 2}$ \\
\hline Total & 100 & 100 & 100 & 100 \\
\hline Totalmente aceite & 9,7 & 10,1 & 3,9 & 4,6 \\
\hline Parcialmente aceite & 18 & 20,3 & 19,4 & 8,6 \\
\hline Recusado & 72,3 & 69,6 & 76,7 & 86,7 \\
\hline
\end{tabular}

Fonte: GEP/MTSS, 2008; GEE/Ministério da Economia, 2011, 2012, 2013. 


\section{O caso da Saúde 24: uma greve ousada em contexto de austeridade reforçada $^{12}$}

Na década de 2000, um conjunto de "mobilizações improváveis" de trabalhadores precários, entre as quais greves em sectores da restauração em França (McDonalds e Pizza Hut) ou em cal centers italianos (como o Atesia, em Roma, com milhares de trabalhadores), suscitaram reflexões importantes sobre a renovação do repertório sindical clássico (Abdelnour et al., 2009; Boumaza e Pierru, 2007; Choi e Mattoni, 2010; Collovald e Mathieu, 2009; Perrin, 2007). Também em Portugal emergiram, a partir de 2002, um conjunto de organizações que se propuseram representar segmentos de trabalhadores precários e cimentar em torno da precariedade identidades de luta e experiências de mobilização (Andrade, 2011; Estanque e Costa, 2012; Soeiro, 2009; 2012). A experiência da greve da Linha Saúde 24 pode ser lida como um exemplo do recurso à "arma da greve" no contexto deste tipo de mobilizações, que procuram reinventar o repertório de luta num quadro de descoletivização, informalização, individualização e remercantilização do trabalho e numa conjuntura marcada pelas políticas de austeridade. A partir deste caso concreto, é possível problematizar as estratégias sindicais e das organizações de precários e o papel que nelas joga o recurso à greve.

\subsection{A Linha Saúde 24: o que é?}

Criada em 2006, a Linha Saúde 24 é uma linha telefónica que tem como objetivo a triagem, o aconselhamento e o encaminhamento em situação de doença. É um serviço da responsabilidade do Ministério da Saúde para "responder às necessidades manifestadas pelos cidadãos em matéria de saúde, contribuindo para ampliar e melhorar a acessibilidade aos serviços e racionalizar a utilização dos recursos existentes" ${ }^{13}$ esclarecendo dúvidas e encaminhando os utentes para o Serviço Nacional de Saúde, quando necessário. A Linha funciona todos os dias do ano, 24 horas por dia e emprega cerca de 400 profissionais, a esmagadora maioria dos quais enfermeiros, que fazem o atendimento telefónico divididos em dois call centers localizados em Lisboa e no Porto, com aproximadamente a mesma dimensão. O vínculo

\footnotetext{
${ }^{12}$ Para uma análise mais desenvolvida deste estudo de caso, cf. Soeiro (2014). Os dados aqui apresentados resultam de uma investigação que incluiu: observação direta de piquetes de greve no mês de janeiro de 2014; quatro entrevistas semidiretivas aprofundadas, realizadas com enfermeiros do Porto e de Lisboa; e análise de conteúdo dos documentos produzidos pelo grupo e publicados no Facebook, das atas da reunião plenária da Assembleia da República de 24 de janeiro de 2014 (publicadas no respetivo Diário, I Série, n. ${ }^{\circ} 41$ ), bem como de comunicados do Sindicato dos Enfermeiros Portugueses.

${ }_{13}$ Informação consultada a 19.02.2014, em http://www.dgs.pt/paginas-de-sistema/saude-de-a-a-z/saude-24.aspx?v=b5ef3 dfe-6f5f-4ce3-8e86-fabad33830bf.
} 
que estes trabalhadores têm com a empresa estabelece-se através de "recibo verde", sendo considerados pela entidade empregadora como "prestadores de serviços", ainda que cumpram horários determinados pela chefia, tenham supervisores e trabalhem nas instalações da empresa.

A importância da experiência e do conhecimento aprofundado sobre o Serviço Nacional de Saúde leva a que o recrutamento valorize a ligação dos profissionais com instituições do SNS, estando a maioria dos enfermeiros-comunicadores a trabalhar, para além das suas funções na Linha, em hospitais públicos, sendo que o seu trabalho na Linha constitui um complemento ao seu salário. Em média, cada enfermeiro trabalha cerca de 18 horas por semana, em turnos. Mas há também quem faça horários completos e tenha ali a sua única fonte de rendimento. O retrato sociográfico revela um grupo tendencialmente jovem, feminizado e qualificado (a formação requerida para a função exige no mínimo uma licenciatura). A grande maioria tem outros empregos para além do que ali exercem com vínculo precário. A pertença sindical é muito reduzida, bem como o é a experiência de ação coletiva no campo laboral.

Por opção governamental, a gestão desta Linha foi entregue a uma entidade privada, através do modelo da parceria público-privada. Assim, os enfermeiros são contratados pela Linha Cuidados de Saúde, SA (LCS), uma empresa pertencente ao Grupo Caixa Seguros e Saúde, SGPS, SA. O contrato de parceria dura até hoje, apesar de em 2011, aquando do seu término, ter havido um novo concurso público, ganho por um consórcio encabeçado pela PT, mas cujo resultado acabaria por ser anulado pelo Tribunal de Contas, que considerou não ter sido "garantida a escolha da melhor proposta” (acórdão n. ${ }^{\circ} 1 / 2013$ de 8 de janeiro). O novo concurso público viria a ser ganho por um outro consórcio, envolvendo novamente a LCS, a Optimus e a Teleperformance. O critério prevalecente na adjudicação foi o preço mais baixo, tendo este consórcio apresentado uma proposta que reduzia para quase metade o valor pago por chamada (de $16 €$ para $7 €$ ). Foi este o motivo invocado pela empresa para avançar, no início de dezembro de 2013, com uma proposta de redução salarial significativa do valor pago aos enfermeiros comunicadores, entre $20 \%$ a $50 \%$, e foi em torno dessa decisão que o conflito laboral se desencadeou levando os trabalhadores a recorrer por duas vezes, no prazo de menos de um mês, à greve.

\subsection{As duas vias do processo de luta}

Podemos situar o primeiro período da mobilização dos enfermeiros da Linha Saúde 24 entre o momento em que os trabalhadores tomam conhecimento da proposta da empresa relativa ao corte nos vencimentos (no início 
de dezembro de 2013) e a primeira greve, que acontece a 4 de janeiro de 2014. Neste período, há uma fase inicial de constituição e estruturação de coletivos de trabalhadores, que os leva de um grupo secreto do Facebook - "Enfermeiros contra os 7 euros à hora" ${ }^{14}$ - à eleição, em plenários realizados no Porto e em Lisboa, de duas comissões informais de trabalhadores. A partir daí, parece haver uma estratégia que segue duas vias paralelas.

Por um lado, existe a via da negociação com a empresa. Ela inicia-se com uma tomada de posição comum dos enfermeiros-comunicadores e com a consequente marcação de uma reunião com elementos da administração, processo no qual se estabelecem os primeiros contactos com o Sindicato dos Enfermeiros Portugueses, que está presente nessa reunião. Manifestam-se aí também as tensões entre as comissões informais e a estrutura sindical, em virtude de visões diferentes sobre o problema, de culturas de intervenção distintas e sobre o tipo de atitude a adotar. A posição sobre a legitimidade e a pertinência do recurso à greve estará no centro desse debate, com o sindicato a desaprovar a paralisação decidida pelos trabalhadores, dado o vínculo os impossibilitar de o fazer de forma legal e os colocar numa situação de redobrada fragilidade.

Por outro lado, desenvolve-se a via de uma intensa intervenção no espaço exterior à empresa, tentando mobilizar recursos externos capazes de compensar uma relação de forças que, no espaço interno, é totalmente desfavorável aos trabalhadores, dado que estes não têm os mecanismos tradicionais que lhes poderiam conferir capacidade negocial no quadro da empresa, desde logo contratos de trabalho ou algum mecanismo de representação coletiva formal. É neste quadro que pode ser entendido o recurso à Autoridade para as Condições de Trabalho, as conferências de imprensa, os pedidos de reunião à Direção-Geral de Saúde, aos Grupos Parlamentares, ao Ministério da Saúde e à Ordem dos Enfermeiros, contactos que vão sendo efetuados entre meados de dezembro de 2013 até ao fim do mês de janeiro de 2014, ou seja, entrando já pela "segunda fase" do processo de luta. Esta segunda linha de intervenção teve nos "Precários Inflexíveis" um aliado determinante.

A segunda fase deste processo de luta pode então situar-se no momento em que a administração da empresa reage, dispensando os "serviços" de dezasseis enfermeiros, numa tentativa de assim decapitar o movimento de contestação entretanto despoletado. Neste período, a causa dos trabalhadores da Linha Saúde 24 assume uma visibilidade pública e mediática maior

${ }^{14}$ O nome faz referência ao valor remuneratório proposto pela administração, que significava uma redução de 1,75 euros por hora. 
e extravasa claramente para o campo político, motivando debates parlamentares (no dia 24 de janeiro, projetos de resolução sobre o assunto são votados no Parlamento), uma segunda paralisação (entre 24 e 27 de janeiro), tomadas de posição públicas da Ordem dos Enfermeiros e da CGTP (ambas nesse dia 27), uma carta de solidariedade com os trabalhadores subscrita por várias personalidades e esclarecimentos da administração publicados nos jornais (a 28 do mesmo mês).

\subsection{Das redes sociais às comissões informais de trabalhadores}

No início do mês de dezembro, a empresa concessionária da Linha Saúde 24 começou a entregar aos trabalhadores uma adenda ao contrato de prestação de serviços que previa a redução salarial a partir de janeiro de 2014, alterando o valor auferido de $8,75 €$ /hora para $7 € /$ hora, e modificando também as regras remuneratórias das horas de qualidade e do horário noturno, cuja bonificação podia ir de $25 \%$ a $100 \%$. Apesar de no início alguns trabalhadores terem assinado a adenda, um grupo de enfermeiros apercebeu-se da dimensão do corte e começou a contestar a proposta. Vários trabalhadores começaram então a recusar assinar a adenda e foi nessa altura que uma das enfermeiras resolve criar um grupo secreto no Facebook, cujos conteúdos podem apenas ser visualizados pelos membros desse grupo, não sendo de acesso público. Para esse grupo, intitulado "Enfermeiros contra os 7 euros à hora", vai convidando os colegas, que o vão transformando na primeira plataforma de comunicação entre os trabalhadores dos dois call centers, de Lisboa e do Porto. A tabela que dá conta do valor real da redução salarial em causa é aí partilhada, faz-se o apelo a que as adendas não sejam assinadas e planeiam-se aí as primeiras ações e os primeiros plenários que viriam a acontecer passados alguns dias. Superando a distância territorial que separava os dois call centers, a resistência contra os cortes começa por ser organizada no espaço virtual. É no Facebook que começam a afirmar-se as lideranças do coletivo e é aí também que é identificada a necessidade de reuniões presenciais.

A primeira destas reuniões acontece em Lisboa, logo no dia 11 de dezembro, numa sala alugada pelo grupo de enfermeiros nuns escritórios em Telheiras e conta com cerca de meia centena de trabalhadores que, de acordo com uma enfermeira, "não cabiam dentro da sala". É dessa reunião que sai a decisão de negociar com a empresa o valor/hora. É também nesse primeiro plenário que se elege, em Lisboa, a comissão informal de trabalhadores, composta por quatro elementos. Decide-se, ainda, reforçar os laços com os trabalhadores do Porto, aproveitando o facto de uma das enfermeiras do call center lisboeta já ter trabalhado ali, o que lhe permitia ir adicionando os colegas do norte ao grupo do Facebook e fazer a ponte com aqueles. $\mathrm{O}$ grupo 
de enfermeiros reunidos resolve, para além da ação junto da administração da empresa, a quem solicitam uma reunião, entrar em contacto com o grupo Precários Inflexíveis, nomeadamente pelo reconhecimento da intervenção pública desta organização no âmbito dos chamados "falsos recibos verdes". O apoio dos Precários Inflexíveis permitirá, como se verá adiante, diversificar as modalidades de ação e sobretudo desenvolver uma estratégia de "conquista da opinião pública", mediatizando o problema, tentando ganhar a simpatia dos utentes e projetando o conflito laboral dos enfermeiros com a LCS para fora do espaço da empresa, disputando-o simultaneamente no debate público, no terreno jurídico e no campo político.

\subsection{Do recurso à $\mathrm{ACT}$ à reunião com a administração}

A primeira ação pública dos trabalhadores foi a entrega de uma queixa à Autoridade para as Condições de Trabalho, para que se realizasse uma ação inspetiva que verificasse a legalidade do vínculo estabelecido entre a LCS e os enfermeiros. O reconhecimento da relação laboral tornava-se decisivo, dado que só nesse quadro os enfermeiros poderiam acionar as proteções, algumas modalidades de ação coletiva e o tipo de negociação previsto entre trabalhadores subordinados e entidade empregadora. Paralelamente, a administração foi confrontada com uma tomada de posição comum dos trabalhadores, através de um abaixo-assinado que contestava o conteúdo da adenda proposta e que propunha à empresa o início de um processo de negociação sobre o valor pago aos enfermeiros. É na sequência desse documento, subscrito por cerca de 300 trabalhadores, que acontece a primeira reunião com o porta-voz da administração.

De acordo com as enfermeiras entrevistadas, nenhum dos membros das comissões informais de Trabalhadores tinha experiência sindical prévia. O contacto com o Sindicato dos Enfermeiros Portugueses é feito, sobretudo, pelo grupo do Porto. A salvaguarda da autonomia na direção do processo de luta é enfatizada, nomeadamente a propósito dessa reunião. Nas palavras de uma das trabalhadoras:

Ficou patente desde o início que quem iria negociar seriamos nós, até porque ele [dirigente sindical] disse que não nos podia representar mesmo que estivéssemos sindicalizados por causa do vínculo laboral [...].

A reunião com o administrador não produz os efeitos desejados pelos enfermeiros. $\mathrm{Na}$ verdade, a direção da empresa recusar-se-á, a partir daí, a receber os elementos das comissões informais de trabalhadores. Pelo contrário, valorizará o diálogo com o Sindicato. 
A administração não aceita reunir connosco, só com o sindicato, que acha bem porque assim evitávamos represálias. Foi quando eu quis criar representantes do sindicato dentro da linha, mas o sindicato não aceitou porque nós éramos recibos verdes.

$\mathrm{Na}$ sequência da tentativa de abrir um processo negocial com a empresa, segue-se uma fase de multiplicação de contactos, por parte das comissões, com entidades exteriores à empresa, em busca de apoio e de mediatização da causa dos enfermeiros. Dois dias depois da reunião com a administração, reúnem com a Direção Geral de Saúde e tentam implicar a Ordem dos Enfermeiros no conflito laboral em curso. Em ambos os casos, contudo, o entendimento de que o problema era de ordem "interna" à empresa é o que predomina nas instituições contactadas. $\mathrm{O}$ insucesso relativo destas reuniões não significou, para os trabalhadores, o abandono da estratégia de visibilização do conflito. A perceção de que era também na opinião pública que podiam ganhar força estava consolidada entre o núcleo dirigente. A greve que é então convocada para o início de janeiro resulta do impasse destas primeiras abordagens. Nesta paralisação, a mediatização e o recurso a formas de resistência que passam por "inundar" a linha de chamadas são duas características importantes.

\subsection{As duas paralisações e as tensões com o sindicato}

A questão do recurso à greve entre trabalhadores sem contrato não é nova. $\mathrm{Na}$ verdade, já em diferentes greves gerais, grupos de trabalhadores a falso recibo verde tinham problematizado o exercício deste direito no caso dos falsos "prestadores de serviços". Se é verdade que o direito à greve é reconhecido pela Constituição, que a lei o considera "irrenunciável" e que está inclusivamente prevista a possibilidade de ela ser decretada por assembleias de trabalhadores da empresa e não apenas pelos sindicatos, não é menos verdade que, do ponto de vista legal, um trabalhador cujo vínculo é considerado "independente" está limitado no reconhecimento formal desse direito. No caso dos enfermeiros da Linha Saúde 24, o recurso à "paralisação" - termo recorrente nas entrevistas realizadas - foi ponderado e decidido pelas reuniões informais de trabalhadores como resposta à situação de inflexibilidade da administração e como ato de solidariedade com os colegas despedidos. Nas palavras de uma trabalhadora:

a 4 de janeiro havia os supostos contratos que terminavam em janeiro, às pessoas que não assinaram foram-lhes retirados os turnos todos, e foi a partir daí que se decidiu essa primeira paralisação como forma de protesto em relação a esses primeiros despedimentos. 
A greve foi o grande momento de visibilidade pública do conflito, dada a atenção mediática que lhe foi conferida. Foi o momento em que a luta dos enfermeiros transbordou claramente para o espaço público, obrigando também os responsáveis da LCS a responder publicamente à ação dos trabalhadores.

Desde o início do processo, a relação com o Sindicato não foi isenta de tensões. Parece faltar um entendimento comum sobre a natureza do vínculo, o que conduzirá à ideia de que, trabalhando aqueles enfermeiros a "recibo verde", algumas modalidades de luta lhes estão vedadas - a greve, por exemplo -, a qual o sindicato não pode legalmente decretar. De acordo com um dos trabalhadores:

O sindicato era contra [...] porque dizem que como nós somos recibos verdes a greve não se aplica a nós, eles não podem decretar a greve. Num hospital eles podem decretar greve, connosco não.

\section{Outra trabalhadora afirma:}

[...] Parámos a linha à revelia do sindicato [...] Mas essa paralisação teve muita visibilidade, comunicação social no Porto, comunicação social em Lisboa, não se falou noutra coisa nesse dia. E então o sindicato queria visibilidade, já esteve no final do dia a falar na televisão.

A primeira paralisação tem uma adesão massiva, cerca de $70 \%$, considerando os dois call centers, sendo mais forte no Porto. É na sequência dessa greve que a empresa reage, dispensando 16 trabalhadores, entre os quais os que haviam dirigido a luta. É também em protesto contra os despedimentos que a segunda greve acontece, no dia em que o Parlamento rejeita dois projetos de resolução que incidiam sobre a regularização contratual da situação dos enfermeiros da Linha e sobre a gestão pública do serviço. Mais uma vez, o recurso à greve não mereceu a concordância do sindicato.

Estas tensões serão exploradas pela própria direção da empresa, que recusará reunir com as comissões informais de trabalhadores, que são quem conduz o processo de luta, mas receberá por várias vezes o sindicato, com quem tentará negociar diferentes acordos. No esclarecimento publicado nos jornais no final do mês de janeiro, a administração não se limita a não reconhecer a paralisação dos trabalhadores como um ato de greve - considera-o um "boicote à atividade da LCS" - mas estabelece também uma distinção clara entre sindicato e comissões, registando que esse 
"boicote" foi promovido pela "comissão ad hoc de enfermeiros entretanto criada, à margem da estrutura sindical representativa destes profissionais". ${ }^{15}$

\subsection{Do conflito laboral ao conflito político}

A passagem do conflito dos enfermeiros com a administração da Linha Saúde 24 para o campo político confere-lhe uma visibilidade acrescida. Logo em meados de dezembro, a comissão informal de trabalhadores envia uma carta aos grupos parlamentares, onde o problema é apresentado a partir dos possíveis impactos negativos decorrentes da "qualidade da Linha", salientando por isso as consequências da decisão não tanto para os trabalhadores (redução da remuneração), mas para os utentes (a qualidade do serviço prestado), de modo a que a questão fosse vista para além da sua dimensão estritamente laboral.

O grupo de enfermeiros é recebido pelos grupos parlamentares do BE, PCP e PSD. Na sequência desses encontros, dois desses partidos apresentam projetos de resolução na Assembleia da República, que seriam discutidos e votados no Plenário da Assembleia da República no dia 24 de janeiro de 2014.

No debate parlamentar, BE e PCP defenderam as suas propostas, criticando a direção da empresa e considerando que a celebração de contratos de trabalho era da responsabilidade do Governo. O PS considerou que o Ministério da Saúde deveria intervir "de forma a que este serviço não seja colocado em causa”. Pelo seu lado, o PSD, pela voz da deputada Graça Mota, defendeu tratar-se de "uma questão eminentemente do foro laboral entre a empresa privada e os profissionais que nela prestam serviço", considerando que "não se deve falar de trabalho dependente, mas, sim, de prestação de serviços de um modo geral". Os projetos seriam chumbados, merecendo os votos favoráveis do PS, PCP, BE e Os Verdes e os votos contra do PSD e do CDS, partidos que suportam o Governo. ${ }^{16}$

A politização do conflito é percecionada de modo ambivalente pelos trabalhadores, que reconhecem o seu efeito na projeção pública do conflito - "foi útil, sem dúvida, isto conseguiu-nos dar toda a visibilidade que nós temos neste momento" - mas também o facto de, desta forma, a sua luta laboral se ter transformado numa "questão partidária", já que, sendo o administrador do PSD, eles estariam "a pagar por tabela".

O alargamento das alianças e a transformação deste conflito numa "luta exemplar" que extravasa a empresa não passou apenas pelo debate

15 LCS, "Linha Saúde 24 - Esclarecimento", Jornal de Notícias, 30 de janeiro de 2014.

${ }^{16}$ No caso do projeto do PCP, foi requerida a votação por pontos, tendo o PS optado pela abstenção em duas das recomendações. 
parlamentar. No dia 28 de janeiro é divulgada uma carta subscrita por 33 personalidades: sindicalistas, especialistas em Direito do Trabalho, académicos, artistas e ativistas precários. Nela, considera-se que o despedimento dos enfermeiros da Linha Saúde 24 constitui "um ataque não apenas a estes trabalhadores, mas a toda a cidadania, e uma ameaça à democracia, porque viola o direito à livre expressão e organização", sendo por isso "urgente defender a democracia, defendendo para isso as pessoas que trabalham na Linha Saúde 24".

Uns dias depois, os enfermeiros entregam junto da Autoridade para as Condições do Trabalho um conjunto de elementos de prova visando o acionamento da Lei contra a Precariedade. No final de fevereiro, o relatório da ACT daria razão a alguns trabalhadores, tendo estes proclamado uma vitória neste terreno e iniciando-se assim um processo judicial, que ainda decorre, para reconhecimento dos seus direitos.

\section{Conclusão: a greve ainda é uma arma?}

No estudo de caso que apresentámos condensam-se algumas das tendências mais representativas do processo de degradação da condição laboral em Portugal. Entre elas está o recurso à subcontratação, nomeadamente por parte do Estado, a promiscuidade entre interesses económicos e redes de cumplicidade política e partidária, o recurso aos "falsos recibos verdes" como mecanismo de contornar as disposições legais relativas à contratação dos trabalhadores, e a precarização nomeadamente de segmentos altamente qualificados. É um exemplo significativo também pelo facto de, contrariando a probabilidade do consentimento, se ter produzido um acontecimento contestatário. É ainda um exemplo pelas características da luta sociolaboral ali levada a cabo em contexto de austeridade: utilização das novas tecnologias como plataforma de encontro e organização; improvisação de mecanismos informais de representação num contexto de descoletivização das relações de trabalho; tensões com os repertórios sindicais clássicos; distância e alguma desconfiança relativamente à natureza da intervenção sindical; externalização do conflito laboral, que passa da empresa para o campo jurídico, político e mediático; repressão do recurso à greve como sendo um "boicote ilegítimo".

Ao agudizar as condições de exploração, a "era da austeridade" abre campo para uma intensificação do protesto. $\mathrm{O}$ exemplo aqui descrito, ou a recente decisão de criação de um sindicato nacional de trabalhadores de call center (em resultado de uma reunião de trabalhadores de call center reunidos em Lisboa a 26.04.2014), vem precisamente ao encontro desta ideia. Mas ao intensificar a precarização, a austeridade também inibe o 
recurso a algumas das modalidades de luta mais significativas na história do movimento operário e sindical. Uma sociologia atenta a este paradoxo deve procurar tornar visíveis e interpretar formas emergentes do conflito social, de organização sindical dos trabalhadores e do recurso à greve, mobilizando os instrumentos da reflexividade científica, também para a luta pelo trabalho digno.

Recebido a 30.01.2014

Aprovado para publicação a 24.04.2014

\section{Referências bibliográficas}

Abdelnour, Sarah; Collovald, Annie; Mathieu, Lilian; Péroumal, Frédéric; Perrin, Evelyne (2009), "Précarité et luttes collectives: renouvellement, refus de la délégation ou décalages d'expériences militantes?”, Sociétés Contemporaines, 74, 73-95.

Andrade, Cristina (2011), Organização de trabalhadoras/es em contextos de precarização. Tese de Mestrado apresentada à Universidade do Porto, Porto, Portugal.

Boumaza, Magali; Pierru, Emmanuel (2007), "Des mouvements de précaires à l'unification d'une cause", Sociétés Contemporaines, 65, 7-25.

Bruun, Niklas (2013), "The Right to Strike and the EU", International Union Rights, 20(2), 8-9. Campos Lima, Maria da Paz; Artiles, Antonio Martin (2011), "Crisis and Trade Union Challenges in Portugal and Spain: Between General Strikes and Social Pacts", Transfer - European Review of Labour and Research, 17(3), 387-402.

Choi, Hae-Lin; Mattoni, Alice (2010), "The Contentious Field of Precarious Work in Italy: Political Actors, Strategies and Coalitions”, WorkingUSA: The Journal of Labor and Society, 13, 213-243.

Collovald, Annie; Mathieu, Lilian (2009), "Mobilisations improbables et apprentissage d'un répertoire syndical”, Politix, 2(86), 119-143.

Coser, Lewis (1956), The Functions of Social Conflict. New York: The Free Press.

Costa, Hermes Augusto (2008), Sindicalismo global ou metáfora adiada? Discursos e práticas transnacionais da CGTP e da CUT. Porto: Afrontamento.

Costa, Hermes Augusto (2010), "Austeridade europeia, protesto europeu: o valor das manifestações transnacionais", Le Monde Diplomatique (edição portuguesa), setembro, n. ${ }^{\circ} 47,24$.

Costa, Hermes Augusto (2011), "Do enquadramento teórico do sindicalismo às respostas pragmáticas", in Elísio Estanque e Hermes Augusto Costa (orgs.), O sindicalismo português e a nova questão social: crise ou renovação? Coimbra: Almedina, 13-48.

Costa, Hermes Augusto (2012a), "Wage Cuts in the Portuguese Public Sector: The Negative Effects of a Court Decision on Labour Relations", Transfer - European Review of Labour and Research, 18(2), 229-231. 
Costa, Hermes Augusto (2012b), "From Europe as a Model to Europe as Austerity: The Impact of the Crisis on Portuguese Trade Unions", Transfer-European Review of Labour and Research, 18(4), 397-410.

Dahrendorf, Ralph (1981), "Elementos para uma teoria do conflito social”, in Sociedade e Liberdade. Brasília: Universidade de Brasília, 133-155 [ed. orig.: 1961].

Dias, Hugo (2012), "Greve”, in Centro de Estudos Sociais (org.), Dicionário das crises e das alternativas. Coimbra: Almedina, 113-114.

DGAEP - Direção Geral da Administração e Emprego Público (2014), "Informação sobre as Greves da AP”. Consultado a 05.03.2014, em http://www.dgap.gov.pt/index. cfm?OBJID=e61955ea-6194-44bc-a938-b6dcbbec5902 e http://www.dgap.gov. pt/index.cfm?OBJID=e32c287d-52c1-4b03-b73e-244ffc561f98.

Estanque, Elísio (2010), “Sociologia da greve”, jornal Público, 24 de novembro, 63.

Estanque, Elísio (2012), A classe média. Ascensão e declínio. Lisboa: Fundação Francisco Manuel dos Santos.

Estanque, Elísio (2013), “O desemprego é uma oportunidade?”, in José Soeiro; Nuno Serra; Miguel Cardina (orgs.), Não acredite em tudo o que pensa. Lisboa: Tinta da China, 73-84.

Estanque, Elísio; Costa, Hermes Augusto (2012), "Labour Relations and Social Movements”, in Denis Erasga (org.), Sociological Landscapes: Theories, Realities and Trends. Rijeka/Croacia: INTECH/Open Acess Publishing, 257-282. Consultado a 22.05.2012, em http://www.intechopen. $\mathrm{com} /$ articles/show/title/labour-relations-and-social-movements.

Estanque, Elísio; Costa, Hermes Augusto; Soeiro, José (2013), “The New Global Cycle of Protest and the Portuguese Case”, Journal of Social Science Education, 12(1), 31-40. Eurostat (2014), Newrelease, Euroindicators 17/2013, consultado a 31.01.2014, em http:// epp.eurostat.ec.europa.eu/portal/page/portal/euroindicators/news_releases.

Fernandes, António Monteiro (2012), “Uma estranha decisão”, jornal Público, 20 de junho, 59

Ferreira, António Casimiro (2012), Sociedade da austeridade e direito do trabalho de exceção. Lisboa: Vida Económica.

Freire, João (2001), Sociologia do trabalho: uma introdução. Porto: Afrontamento.

GEE - Gabinete de Estratégia e Estudos, Ministério da Economia (2011, 2012, 2013), Estatísticas em Síntese - Greves 2010 Continente. Consultado a 05-03-2014, em http://www.gee.min-economia.pt/.

GEP/MTSS (2008), Séries Cronológicas GREVES 1986 - 2007. Consultado a 05-03-2014, em http://www.gep.msess.gov.pt/estatistica/greves/seriegreves_1986_2007.pdf.

Gall, Gregor (2012), "Quiescence Continued? Recent Strike Activity in Nine Western European Economies”, Economic and Industrial Democracy, 34(4), 667-691.

Giraud, Baptiste (2005), "Conditions et dynamiques de la transformation des usages syndicaux de la grève”. Comunicação realizada no $8 .^{\circ}$ Congresso da Association 
Française de Science Politique, na mesa redonda "Où en sont les théories de l'action collective ?", 1-17 (mimeo).

Giubboni, Stefano; O’Brien, Charlotte (2009), “The Right to Strike: Fundamental Principle or Fetter?" in ESA (org.), Full papers, 9th Conference of the European Sociological Association - European Society or European Societies? (Research Network 17, Industrial Relations, Labour Market Institutions and Employment) Lisboa: ISCTE/ IUL, 1-18 [edição em CD-Rom].

Gomes, Pedro Botelho (2012), "Uma bomba atómica social?", jornal Público, 24 de junho, consultado a 24.06.2012 em http://www.publico.pt/opiniao/ jornal/uma-bomba-atomica-social-24772823??.

Hyman, Richard (2012), "Can a Crisis be an Opportunity? The Challenges of Strategy and Democracy”. Comunicação do Opening Plenary da Industrial Relations in Europe Conference (IREC) e da ESA Research Network "Work, Employment and Industrial Relations” (RN 17), realizada em Lisboa (ISCTE), a 6 de setembro.

ICTWSS (2013), "Database on Institutional Characteristics of Trade Unions, Wage Setting, State Intervention and Social Pacts in 34 countries between 1960 and 2007”. Consultado a 05.03.2014, em http://www.uva-aias.net/208.

IUR (2013), “Editorial: A Right we Must Defend”, International Union Rights, 20(2), 2. Leite, Jorge; Costa, Hermes Augusto; Silva, Manuel Carvalho; Almeida, João Ramos (2013), “Austeridade, reformas laborais e desvalorização do trabalho”, in Observatório sobre Crises e Alternativas (org.), A anatomia da crise: identificar os problemas para construir alternativas (1. ${ }^{\circ}$ relatório/preliminar). Coimbra/Lisboa: Observatório sobre Crises e Alternativas, 108-160.

MTSS (2006), Livro Verde Sobre as relações laborais. Lisboa: MTSS.

Observatório do Emprego e Formação Profissional, Região Autónoma dos Açores (2009, 2010, 2011, 2012, 2013), "Estatística de Greves”. Consultado a 05.03.2014, em http://www.azores.gov.pt.

Olson, Mancur (1998), A lógica da acção colectiva: bens públicos e teoria dos grupos. Oeiras: Celta [ed. orig.: 1965].

Ortiz, Isabel; Burke, Sara; Berrada, Mohamed; Cortés, Hernán (2013), World protests 2006-2013. Initiative for Policy Dialogue, Columbia University, New York/Friedrich-Ebert-Stiftung.

Pedersini, Roberto (2010), "Trade Union Strategies to Recruit New Groups of Workers", electronic Report. Dublin: Eurofound. Consultado a 05.03.2014, em http://www. eurofound.europa.eu/eiro/studies/tn0901028s/tn0901028s.htm.

Perrin, E. (2007), "Nouvelles formes d'expression des conflits du travail dans les luttes de précaires", Revue multidisciplinaire sur l'emploi, le syndicalisme et le travail (REMEST), 2(2), 48-64.

Rebelo, Glória (2012), “Tempo e condições de trabalho”, jornal Público, 6 de abril, 56. Rebelo, José; Brites, Rui (2012), A comunicação sindical da CGTP-IN. Lisboa: CGTP. 
Rosas, Fernando (2012), "Uma Mudança de Paradigma”, Vírus, 1, 10-16.

Santos, Boaventura de Sousa (2004), "Teses para a renovação do sindicalismo em Portugal, seguidas de um apelo”, in Elísio Estanque; António Casimiro Ferreira; Hermes Costa; Leonardo Mello e Silva; Roberto Veras (orgs.), Relações laborais e sindicalismo em mudança - Portugal, Brasil e o contexto transnacional. Coimbra: Quarteto, 161-180.

Santos, Boaventura de Sousa (2012), Portugal. Ensaio contra a autoflagelação. Coimbra: Almedina.

Secretaria Geral da Educação e Recursos Humanos, Região Autónoma da Madeira (2014), “Greves exclusivamente regionais. Ano 2013”. Consultado a 05.03.2014, em http://srrh.gov-madeira.pt/Portals/5/Estatistica/Greves\%20regionais_ Ano\%202013.\%20Word.pdf.

Silva, Manuel Carvalho da (2002), Agir contra a corrente: reflexões de um sindicalista. Porto: Campo das Letras.

Silva, Manuel Carvalho da (2012), Vencer o medo - ideias para Portugal. Lisboa: Temas e Debates.

Soeiro, José (2009), "Hipóteses sobre os movimentos de precários em Portugal”, in FERVE (org.), Dois anos a ferver. Retratos da luta, balanço da precariedade. Porto: Afrontamento.

Soeiro, José (2012), “'Perdi o emprego, encontrei uma ocupação’. Juventude, precariedade e o novo ciclo de protesto global“, in Giovanni Alves; Elísio Estanque (orgs.), Trabalho, juventude e precariedade. Barau, São Paulo: Editorial Praxis.

Soeiro, José (2014), "Geração precária? Trajetórias, vivências, subjetividade colectiva e discurso público sobre a precariedade dos jovens em Portugal”, Investigação de doutoramento em curso financiada pela Fundação para a Ciência e Tecnologia (SFRH/BD/48470/2008).

Sousa, Henrique José Carvalho (2011), "Sindicalização: a vida por detrás das estatísticas (alguns problemas metodológicos)", Working Paper, Projecto Sociedade Civil e Democracia, FCSH-UNL.

Standing, Guy (2011), The Precariat. The New Dangerous Class. London: Bloomsbury. Stoleroff, Alan (2013), "A crise e as crises do sindicalismo: há uma revitalização possível?”, in Raquel Varela (org.) A segurança social é sustentável. Trabalbo, Estado e segurança social em Portugal. Lisboa: Bertrand, 207-239. 